\title{
Responses of Chironomidae (Diptera; Insecta) to the exclusion of shrimps and Ephemeroptera in a coastal forest stream, Rio de Janeiro, Brazil
}

\author{
Souza, ML., Moulton, TP.*, Silveira, RML., Krsulović, FAM. and Brito, EF. \\ Departamento de Ecologia, IBRAG, Universidade do Estado do Rio de Janeiro, \\ Rua São Francisco Xavier, 524, CEP 20550-011, Rio de Janeiro, RJ, Brazil \\ *e-mail: moulton@uerj.br \\ Received December 29, 2004 - Accepted June 28, 2005 - Distributed February 28, 2007
}

(With 3 figures)

\begin{abstract}
In a benthic community on a continuous flat granite substrate in a third-order coastal forest stream, the dominant chironomid (Cricotopus) increased in number when shrimps (Macrobrachium olfersi and Potimirim glabra) and baetid ephemeropterans were excluded by electricity. The response appeared to be mediated by an increase in periphyton and sediments, rather than a reduction of direct predation or interference. Chironomids, periphyton and sediments decreased significantly compared to the control when shrimps only were excluded. Baetid ephemeropteran appeared to be the most important determinants of periphyton and sediment mass; the density of chironomids appeared to follow the quantity of periphyton and sediments.
\end{abstract}

Keywords: Cricotopus, electric exclusion, Macrobrachium, Baetidae, periphyton.

\section{Respostas de Chironomidae (Diptera; Insecta) à exclusão de camarões e Ephemeroptera em um córrego costeiro de Mata Atlântica, Rio de Janeiro, Brasil}

\begin{abstract}
Resumo
Os quironomídeos dominantes (Cricotopus) de uma comunidade bentônica aumentaram em densidade quando camarões (Macrobrachium olfersi e Potimirim glabra) e efemerópteros betídeos foram excluídos por eletricidade de um substrato rochoso contínuo em um córrego de Mata Atlântica. Esta resposta parece ter sido mais influenciada por um aumento no perifíton do que pela redução da predação direta ou competição por interferência. Quando somente os camarões foram excluídos, os quironomídeos, perifíton e sedimentos sofreram redução significativa em comparação com os controles. Efemerópteros betídeos parecem ter sido os maiores determinantes da quantidade de sedimentos e perifíton; a densidade de quironomídeos parece seguir a quantidade de perifíton e sedimentos.
\end{abstract}

Palavras-chave: Cricotopus, exclusão por eletricidade, Macrobrachium, Baetidae, perifíton.

\section{Introduction}

Chironomidae are commonly found in freshwater food chains. Their trophic status appears to be quite varied; many species are detritivores acting as filterers, gatherers and scrapers (Merritt and Cummings, 1996). Some species are herbivores of periphyton (algae, heterotrophic organisms and organic matter), others predators. They are often described as part of the diet of other organisms (Armitage, 1990). Less is known about their quantitative importance in food webs. Relatively few studies have determined the controlling factors concerning their abundance.

We studied a benthic community in which we supposed that shrimps, baetid ephemeropterans, chironomids and periphyton interacted strongly (Figure 1). We sought to elucidate the controlling factors in the chironomid populations by excluding shrimps, which were probable predators and possible competitors, and baetid ephemeropterans, which were possible competitors of chironomids. We expected that if the chironomid population were controlled by "top-down" processes (predation), then the removal of their predators would cause an increase in their numbers. On the other hand, if "bottomup" control were more important, the removal of competition and subsequent freeing of resources (periphyton) would cause chironomids to increase. The increases would, of course, be caused through immigration of larvae, not reproduction. 


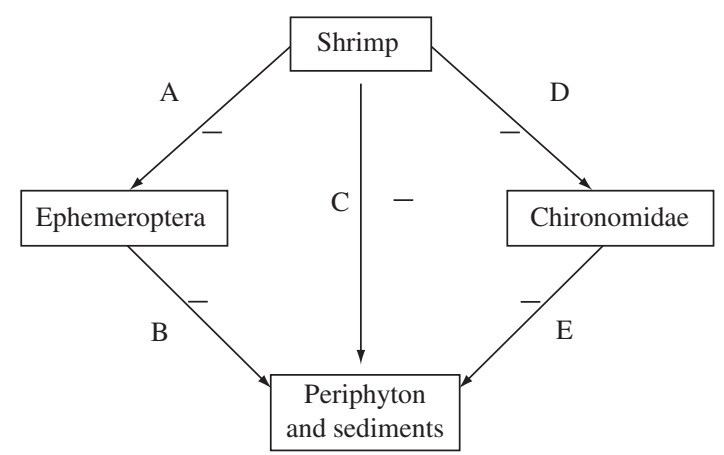

Figure 1. Interactions among the components of the community. Only the feeding or negative interactions are presented here; obviously there exist positive feedbacks of prey to predator, periphyton to herbivore, etc. that are not indicated. Experimental results indicated that interactions A and B were important for periphyton dynamics. The positive effect of periphyton and sediments (reverse of E) was important for chironomid dynamics.

It is notoriously difficult, however, to predict the behaviour of food webs because of the indirect effects inherent in all but the simplest of webs (Pimm, 1982; Wootton, 1994; Yodzis, 1988). Often counter-intuitive results occur due to indirect effects. For example, in many aquatic systems, an exclusion of top predators causes an indirect increase at the next lower level and decrease at two levels below the top - the so-called "trophic cascade" (Pace et al., 1999). Power et al. (1992) and Crowl et al. (1997) observed trophic cascades in stream communities. On the other hand, other researchers have observed the absence of trophic cascades in simple stream communities in Puerto Rico (Pringle and Blake, 1994) and more complex communities in Costa Rica (Pringle and Hamazaki, 1998) and suggested that large omnivores (shrimps and fishes) might not cause trophic cascades because they acted at two levels of the food chain. Previous experiments at our study site led us to expect a strong indirect action of shrimp on the substrate (Siviero and Moulton, 1998) and strong direct grazing by ephemeropterans (Siviero, 1999). Computer simulation predicted that the chironomid population should react to the changes induced in the other components of the system (Silveira and Moulton, 2000). In a different site of the Rio Andorinha, Souza and Moulton (2005) found that the small herbivorous shrimp Potimirim glabra was more important in removing periphyton rather than interacting negatively with the ephemeropterans.

A further aspect of our work was the question of how chironomids affect the periphyton and sediments in which they live. Removing large macroinvertebrates (shrimps and ephemeropterans) allowed chironomids to act free from predator (shrimps) and competitor (shrimps and ephemeropterans) pressures. By doing this we intended to reveal the dynamics of chironomids and the periphyton matrix. Computer simulation predicted that they should track changes in the periphyton (Silveira and Moulton, 2000).

\section{Materials and Methods}

\subsection{Study site}

We studied the benthic community of a continuous rock substratum at the locality "Mãe D'água" of the third-order stream Rio Andorinha, Ilha Grande, RJ (Figure 2). Immediately upstream was a large pool and downstream a steeply-inclined rock face. The depth of the experimental area varied from 20 to $9 \mathrm{~cm}$. The macroinvertebrate community in this area was depauperate compared to areas with boulders or to the inclined rock face, and comprised 4 species of Baetidae, Ephemeroptera (Cloeodes, Baetodes, Americabaetis and Dactylobaetis) and 4 species of Chironomidae, Diptera, of the sub-families Orthocladiinae (Cricotopus), Tanypodinae (2 species) and Chironominae (Beardius). Other macroinvertebrates were very rare, although Trichoptera, Plecoptera and other groups were common on the nearby inclined rock face (Moulton and Souza, 1998). Macrobrachium olfersi Wiegmann, 1836 (Decapoda: Palaemonidae), and Potimirim glabra Kingsley, 1878 (Decapoda: Atyidae), are the two shrimp species inhabiting the pool and were active in the study area at night. The pool had a single species of fish Characidium japuhybensis Travassos, 1949, which we never saw in the experimental areas.

\subsection{Exclusion}

We used electric exclosures to exclude fauna from delimited areas, basing this on the pioneering work of Pringle and Blake (1994). We used two brands of electrifier, which are normally used to exclude domestic stock from pasture by supplying high voltage, low amperage millisecond pulses of electricity to an electric fence. We connected the electrifiers to copper wires, which we attached directly to the rock substrate. The electrifier of lower intensity, Ballerup brand, excluded shrimps only, as in Pringle and Blake (1994); the electrifier of higher intensity, Speedrite 5000, excluded both shrimps and ephemeropterans as in Brown et al. (2000). Chironomids were apparently unaffected by the electrical treatments. We set up three experimental areas of $180 \times 30 \mathrm{~cm}$ each with three parallel wires attached longitudinally to the substrate (Moulton et al., 2004). Two areas were electrified by attaching the outside wires to the cathode and the inside wire to the anode of the two electrifiers; the third area served as a control.

\subsection{Sampling and analysis}

We sampled inside the experimental areas for macroinvertebrates using a $10 \times 10 \mathrm{~cm}$ Surber apparatus (200 $\mu \mathrm{m}$ mesh) and for periphyton and sediments using a plunger, brush and syringe device. Each area was sampled by each method four times on three occasions, days 0,6 and 15 after electrical exclusion was activated. Day 0 was on 22 January, 2000. Additionally we visually counted shrimps and ephemeropterans in the three areas by day and at night on most of the days of the experiment. Macroinvertebrates from Surber samples 


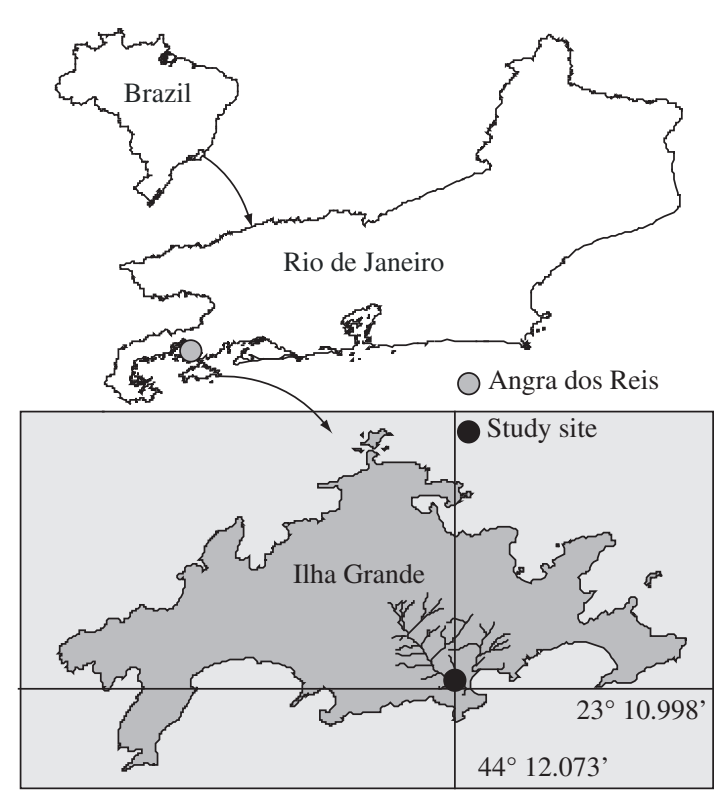

Figure 2. Location of the study site on the coastal island Ilha Grande, Rio de Janeiro state.

were counted under stereo microscope (40x magnification). For the quantification of periphyton and organic sediments, we report here the results of dry mass (DM), which was obtained by filtering, drying for 24 hours at $60{ }^{\circ} \mathrm{C}$ and weighing $( \pm 0.001 \mathrm{~g})$ the samples.

We analyzed the log-transformed DM $\left(\mathrm{g} / \mathrm{m}^{2}\right)$ and the density of Cricotopus (individuals $/ \mathrm{m}^{2}$ ) by the sampling day using the replicate measures within treatments in 1-way analysis of variance (ANOVA). Significant differences among means $(p<0.05)$ were identified using Tukey's Multiple Range Test.

\section{Results}

We directly observed that the lower intensity electrical treatment excluded shrimps totally. The higher intensity treatment excluded shrimps and larger ephemeropterans totally (greater than $1.5 \mathrm{~mm}$ of body length) and most of the smaller ephemeropterans (less than $1.5 \mathrm{~mm}$ of body length). Smaller ephemeropterans $(0.56 \pm 0.23 \mathrm{~mm}$; mean \pm S.D) that remained inside the high electrical intensity exclosure appeared to have an electrical shock as they twitched in rhythm with the electrical pulses. This possibly reduced their feeding activity.

The substrate of the high intensity electrical exclosure (shrimps + ephemeropterans) darkened visibly by day 15 and the quantity of periphyton and sediments (DM) was significantly higher in this treatment compared to the other two treatments (1-way ANOVA, $F_{2,9}=33.1, \mathrm{p}<0.001$ ), (Figure 3a). In the low intensity electrical exclosure (shrimps only), the DM was signifi-
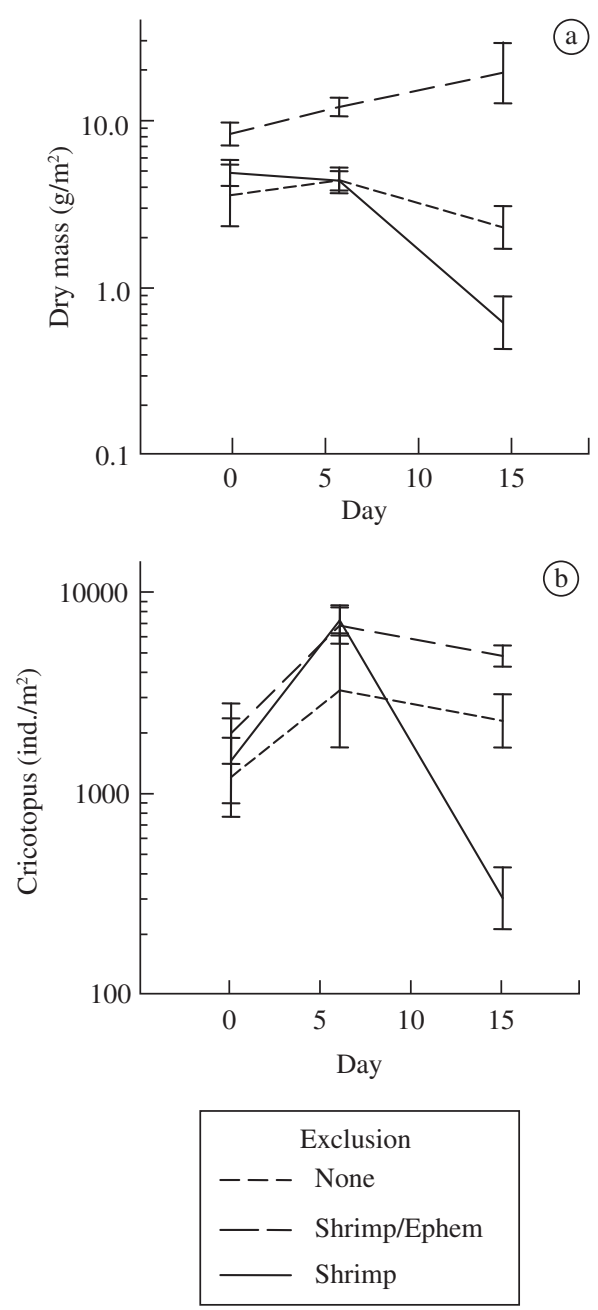

Figure 3. Response of DM a) and Cricotopus b) to electrical exclusions (mean $\pm 1 \mathrm{SE}, \mathrm{n}=4$ ). The statistically significant differences in DM among treatments were followed by the density of Cricotopus on day 15. Significant differences among means $(\mathrm{p}<0.005)$ were identified using Tukey's Multiple Range Test.

cantly less than that of the other treatments after 15 days (Figure 3a).

The density of Cricotopus followed the same pattern as that of DM (Figure 3b). After 15 days the three treatments were significantly different (one-way ANOVA of log-transformed data, $\left.F_{2.9}=38.1, \mathrm{p}<0.001\right)$; Cricotopus sp. density ( $4900 \pm 22$ individuals $/ \mathrm{m}^{2}$; mean $\left.\pm 1 \mathrm{SE}\right)$ was non-significantly higher in the treatment without shrimps and ephemeropterans and significantly lower in the treatment without shrimps $\left(350 \pm 119\right.$ individuals $/ \mathrm{m}^{2}$; mean $\pm 1 \mathrm{SE})$ in comparison to the control (2525 \pm 620 individuals $/ \mathrm{m}^{2}$; mean $\pm 1 \mathrm{SE}$ ). The other three species of Chironomidae were not abundant enough to show a clear response or to be statistically analyzed. 
The results on day 6 were significantly different among treatments for DM (one-way ANOVA of logtransformed data, $F_{2.9}=22.7, \mathrm{p}<0.001$ ), but not for Cricotopus sp. density $\left(F_{2.9}=1.7, \mathrm{p}<0.233\right)$; they appeared to be influenced by heavy rain $(33.2 \mathrm{~mm} /$ day $)$ and high water flow (depth increased $c a .20 \mathrm{~cm}$ in the experimental area) on day 5 .

\section{Discussion}

Ephemeropterans appear to have a dominant effect on the periphyton and sediments of this community; when they were excluded with the shrimps, the periphyton and sediments were an order of magnitude higher than the control on day 15 (Figure 3). On the other hand, the periphyton and sediments decreased significantly when shrimps only were excluded and the ephemeropterans could forage freely on the substrate. The dominant genus of chironomid, Cricotopus, appeared to respond directly to the shift in periphyton and sediments; it appears to be controlled by the "bottom-up" supply of detrital food and perhaps habitat (Figure 3).

In this experiment, Cricotopus did not respond positively to the absence of its potential predators, the shrimps. It is possible that an initial positive response was masked by the high-flow event on day 5 . At the end of the experiment, the no-shrimp treatment had significantly less periphyton and sediments and concomitantly lower Cricotopus density. We tentatively interpret this as indicating that the negative effect of less periphyton and sediments was stronger or more direct than the positive effect of fewer predators. We suspect that the reduced periphyton and sediments was caused by a trophic cascade provoked by the exclusion of shrimps whereby ephemeropterans graze the substrate more intensively. Other experiments with cage exclusion (Siviero and Moulton, 1998) and electric exclusion (Silveira and Moulton, 2000) confirmed this effect, although the phenomenon did not occur in all experiments (Moulton et al., 2004).

A corollary to this result is that Cricotopus did not appear to be important in the dynamics of the periphyton and sediments; it responded positively to increased periphyton and sediments but did not diminish them by its activities. It could be argued that the experiment did not proceed long enough to show a potential negative effect of increased Cricotopus on periphyton and sediments, but we consider this unlikely in the light of our other unpublished observations of experiments of this type.

The results of this experiment are weakened by the lack of replication of the treatments; our replicate measurements of DM and chironomid density were taken within single treated areas. We have, however, observed similar reactions of chironomid density, periphyton and sediments in other experimental exclusion of shrimps and shrimps-plus-ephemeropterans (Siviero, 1999; Silveira and Moulton, 2000; Moulton et al., 2004; Souza and Moulton, 2005), and we are confident that the present results can be repeated for this community.
Acknowledgments - The Centre for Environmental Studies and Sustainable Development (CEADS), a campus of UERJ at Ilha Grande, supplied logistic support and hospitality for which we are greatly appreciative. We thank our colleagues who helped with field and laboratory work and Ana Oliveira (Laboratório de Entomologia, UFRJ) who helped in identifying the chironomids.

\section{References}

ARMITAGE, PD., 1995. Chironomidae as food. In The Chironomidae: Biology and ecology of non-biting midges, eds. PD. Armitage, PS. Cranston, and LCV. Pinder, p. 423-435. Chapman and Hall, London.

BROWN, GC., NORRIS RH., MAHER WA. and THOMAS K., 2000. Use of electricity to inhibit macroinvertebrate grazing of epilithon in experimental treatments in flowing waters. $J$. North Am. Benthol. Soc., vol. 19, no. 1, p. 176-85.

CROWL TA., TOWNSEND CR., BOUWES N. and THOMAS H., 1997. Scales and causes of patchiness in stream invertebrate assemblages: top-down predator effects? J. North Am. Benthol. Soc., vol. 16, no. 1, p. 277-85.

MERRITT, RW. and CUMMINS, KW., 1996. An introduction to the aquatic insects of North America, 3th ed. Kendall/Hunt, Duque, Iowa, USA, $722 \mathrm{p}$.

MOULTON TP. and SOUZA ML., 1998. Comparisons of the benthic community dynamics of a freshwater stream rock-face and the marine intertidal. Anais do IV Simpósio de Ecossistemas Brasileiros; Águas de Lindóia, SP. São Paulo: ACIESP, 237-43.

MOULTON TP., SOUZA ML., SILVEIRA RLM. and KRSULOVI FAM., 2004. Effects of ephemeropterans and shrimps on periphyton and sediments in acoastal stream (Atlantic forest, Rio de Janeiro, Brazil). J. North Am. Benthol. Soc., vol. 23, no. 4, p. 868-881.

PACE ML., COLE JJ., CARPENTER SR. and KITCHELL JF., 1999. Trophic cascades revealed in diverse ecosystems. Trends in Ecology and Evolution, vol. 14, no. 12, p. 483-8.

PIMM SL., 1982. Food webs. London, Chapman \& Hall, 219 p.

POWER ME., MARKS JC. and PARKER MS., 1992. Variation in the vulnerability of prey to different predators - Communitylevel consequences. Ecology, vol. 73, no. 6, p. 2218-23.

PRINGLE CM. and BLAKE GA., 1994. Quantitative effects of atyid shrimp (Decapoda: Atyidae) on the depositional environment in a tropical stream: Use of electricity for experimental exclusion. Can. J. Fish. Aquat. Sci., vol. 51, no. 6, p. 1443-50.

PRINGLE CM. and HAMAZAKI T., 1998. The role of omnivory in a Neotropical stream: Separating diurnal and nocturnal effects. Ecology, vol. 79, no. 1, p. 269-80.

SILVEIRA RLM. and MOULTONTP., 2000. Modelling the food web of a stream in Atlantic forest. Acta Limnol. Bras., vol. 12, p. 63-71.

SIVIERO FN., 1999. Influência de crustáceos na comunidade perifítica em um córrego de Mata Atlântica na Ilha Grande, RJ. Unpublished Bachelors monograph. Rio de Janeiro: IBRAG, Universidade do Estado do Rio de Janeiro.

SIVIERO FN. and MOULTON TP., 1998. Influência de crustáceos na comunidade de fitobêntos de um córrego da Mata 
Atlântica, Rio Barra Grande, na Ilha Grande, RJ. Anais do IV Simpósio de Ecossistemas Brasileiros; Águas de Lindóia, SP. São Paulo: ACIESP, p. 426-31.

SOUZA ML. and MOULTON TP., 2005. The effects of shrimps on benthic material in a Brazilian island stream. Freshwater Biology, vol. 50, no. 4, p. 592-602.
WOOTTON JT., 1994. The nature and consequences of indirect effects in ecological communities. Annu. Rev. Ecol. Syst., vol. 25 , no. 25 , p. 443-66.

YODZIS P., 1988. The indeterminacy of ecological experiments as perceived through perturbation experiments. Ecology, vol. 69 , no. 2 , p. $508-15$. 